УДК 343.26

DOI https://doi.org/10.32849/2663-5313/2020.2.50

Олена Ющик,

канд. юрид. наук,

дочент кафедри кримінального права

юридичного факультету

Чернівещького національного університету імені Юрія Федъковича

\title{
ОБМЕЖУВАЛЬНІ ЗАХОДИ, ЩО ЗАСТОСОВУЮТЬСЯ ДО ОСІБ, ЯКІ ВЧИНИЛИ ДОМАШНЕ НАСИЛЬСТВО
}

Стаття присвячена інституту обмежувальних заходів, які застосовуються до осіб, які вчинили домашнє насильство. У межах ивого дослідження проведено аналіз заходів, які передбачені статтею 91-1 Кримінального кодексу Украӥни. Встановлено, що в теорії кримінального права та судовій практииі існують неоднозначні трактування заходів, які можуть застосовуватись до осіб, які вчинили домашнє насильство. Наголошено, що обмежувальні заходи застосовуються до особи, якій призначено покарання, яке не пов'язано з позбавленням волі, тому останні покликані виконати функиію виправлення особи, без ізолячії від суспільства, а також запобігти злочинам, пов'язаним із домашнім насильством. З'ясовано наявність низки проблем у застосуванні обмежувальних заходів, оскільки вони не узгоджуються з нормами інший галузей права. Крім того, деякі заходи обмежують права та свободи особи, наприклад, обмеження ї̈ пересування або можливості користування власним житлом. Необхідо пам'ятати, що до особи, яка вчинила злочин, можуть застосовуватись обмеження, але вони не повинні порушувати ї права та законні інтереси. Також варто зазначити, що застосування обмежувальних заходів покликане захистити та відновити порушені права осіб, які зазнали фізичного, психологічного або економічного насильства. Саме внесення змін до кримінального законодавства є наслідком імплементачії Конвениії Ради Свропи про запобігання насильству стосовно жінок і домашньому насильству та боротьбу із иими явищами. Досліджуваний інститут повинен послужити стримувальним інструментом у сфері протидї домашньому насильству, що дозволить захистити право людини на свободу від насильства. Тому погоджуємося із вченими та практиками стосовно того, що застосування обмежувальних заходів повинно забезпечити зменшення кількості випадків домашнього насильства в суспільстві.

Ключові слова: домашне насильство, обмеження, заходи, пробаційна програма, програма кривдника, кримінальна відповідальність.

Постановка проблеми. 11 січня 2019 р. набрав чинності Закон України «Про внесення змін до Кримінального та Кримінального процесуального кодексів з метою реалізації положень Конвенції Ради Свропи про запобігання насильству стосовно жінок і домашньому насильству та боротьби з цими явищами» [1], ухвалений Верховною Радою України 6 грудня 2017 р. Відповідно до цього Закону, до Загальної частини Кримінального кодексу (далі - з КК) України внесено p. XIII-1, який містить норму, що передбачає обмежувальні заходи, що застосовуються до осіб, які вчинили домашнє насильство (ст. 91-1 КК України). Сучасна судова практика показує, що застосування таких заходів необхідне в разі притягнення осіб до кримінальної відповідальності за вчинення домашнього насильства. Саме застосування обмежувальних заходів повинно виконувати превентивну функцію стосовно ско- єння таких діянь, які пов’язані з насильством щодо жінок, домашнім насильством. Тому доцільно розглянути особливості вжиття таких заходів у правозастосовчій практиці.

Сьогодні проблемам застосування обмежувальних заходів присвячено небагато публікацій у зв'язку 3 їхньою новизною у кримінальному законодавстві. Серед науковців, які досліджували ці питання, такі: Д.М. Дікова-Фаворська, І.В. Жук, П.В. Кравець, Д.С. Крикливець, О.В. Чорна, В.В. Шаблистий, А.М. Ященко й ін.

Мета статті - розкрити теоретичні аспекти та виявити на підставі судової практики проблеми застосування обмежувальних заходів щодо осіб, які вчинили домашне насильство.

Виклад основного матеріалу. Зміни у Кримінальний кодекс України внесено на підставі реалізації положень Конвенції Ради 
Європи про запобігання насильству стосовно жінок і домашньому насильству та боротьбу із цими явищами [2]. Цілі цієї Конвенції такі: а) захист жінок від усіх форм насильства й недопущення, кримінальне переслідування та ліквідація насильства стосовно жінок і домашнього насильства; b) сприяння ліквідації всіх форм дискримінації стосовно жінок і заохочення дійсної рівності між жінками та чоловіками, зокрема шляхом надання жінкам самостійності; с) розроблення всеосяжних рамок, політики та заходів для захисту всіх жертв насильства стосовно жінок і домашнього насильства, надання їм допомоги; d) заохочення міжнародного співробітництва 3 метою ліквідації насильства стосовно жінок і домашнього насильства е) забезпечення підтримки та надання допомоги організаціям і правоохоронним органам в ефективному співробітництві для застосування комплексного підходу до ліквідації насильства стосовно жінок і домашнього насильства.

До КК України була внесена норма, яка передбачає кримінальну відповідальність за домашне насильство (ст. 126-1). До особи, яка вчинила таке діяння, водночас із призначенням покарання, не пов'язаного $з$ позбавленням волі, або звільненням із підстав, передбачених Кримінальним кодексом, від кримінальної відповідальності чи покарання, суд може застосувати обмежувальні заходи, які передбачені у ст. 91-1 КК України. До особи можуть бути застосовані один або декілька таких заходів.

Конвенція Ради Свропи про запобігання насильству стосовно жінок і домашньому насильству та боротьбу із цими явищами (ст. 53) ставить за умови, що зазначені обмежувальні заходи мають бути доступними для жертв усіх форм домашнього насильства, водночас повинні бути: а) доступними для невідкладного захисту та без покладення неналежного фінансового або адміністративного тягаря на жертву; б) виданими на певний період або до їх зміни чи зняття; в) у разі необхідності виданими на основі ex parte, що має негативну дію; г) доступними незалежно від іншого правового провадження або на додаток до нього; д) дозволеними бути представленими в подальшому правовому провадженні [3, с. 269].

Як зазначає А.М. Ященко, обмежувальні заходи кримінально-правового характеру сьогодні закріплені у кримінальному законодавстві більшості європейських країн. Зокрема, їх регламентовано у кримінальному законодавстві Королівства Іспанії, Французької Республіки, Республіки Польща та багатьох інших країн [4, с. 35-45].
Отже, ст. 91-1 КК України передбачає такі види обмежувальних заходів, як:

1) заборона перебувати в місці спільного проживання з особою, яка постраждала від домашнього насильства;

2) обмеження спілкування 3 дитиною в разі, якщо домашне насильство вчинено стосовно дитини або в її присутності;

3) заборона наближатися на визначену відстань до місця, де особа, яка постраждала від домашнього насильства, може постійно чи тимчасово проживати, тимчасово чи систематично перебувати у зв'язку з роботою, навчанням, лікуванням чи з інших причин;

4) заборона листування, телефонних переговорів з особою, яка постраждала від домашнього насильства, інших контактів через засоби зв'язку чи електронних комунікацій особисто або через третіх осіб;

5) направлення для проходження програми для кривдників або пробаційної програми.

Вказані обмежувальні заходи суд має право застосовувати, як показує судова практика, не завжди вони зазначені у вироці про призначення покарання за домашнє насильство. Оскільки ці заходи застосовуються, як визначає закон, в «інтересах потерпілого», як визначено у ст. 52 Конвенції Ради Свропи про запобігання насильству стосовно жінок i домашньому насильству та боротьбу із цими явищами, «у ситуаціях безпосередньої небезпеки», то суд не може застосовувати до особи, яка вчинила домашне насильство, обмежувальні заходи, проігнорувавши позицію потерпілого і не пояснивши у вироку чи ухвалі, чому саме він не застосував жодного із зазначених заходів.

Перший обмежувальним заходом, який може застосувати суд, - це заборона перебувати в місці спільного проживання з особою, яка постраждала від домашнього насильства. У п. 264 Пояснювальної доповіді до Конвенції Ради Європи про запобігання насильству стосовно жінок і домашньому насильству та боротьбу із цими явищами зазначено, що в ситуаціях безпосередньої небезпеки найефективніший спосіб гарантувати безпеку жертві домашнього насильства - забезпечення фізичної дистанції між жертвою та її кривдником. У разі застосування такого заходу особа-кривдник зобов'язана виїхати зі спільного місця проживання на певний період, водночас залишити жертву в місці спільного проживання. Прикладом застосування такого заходу є вирок Петропавлівського районного суду Дніпропетровської області від 7 листопада 2019 р. До Особи 1, яка вчинила злочин, передбачений у ст. 126-1 КК України, судом було засто- 
совано обмежувальний захід, який передбачає заборону перебувати в місці спільного проживання з потерпілою Особою 2, яка постраждала від домашнього насильства [5].

У разі застосуванні такого обмежувального заходу постає питання щодо необхідності наділити відповідні органи повноваженнями, які дозволять їм наказувати винному в домашньому насильстві залишити житло і забороняти йому повертатися і спілкуватися із жертвою. Уважаємо, що таким органом повинен бути центр пробації, який виконую належні функції з роботи із пробаційними програмами кривдників.

Цікавою є думка Д.Є. Крикливця, який зазначає, що обмежувальні заходи можуть застосовуватись на строк від одного до трьох місяців і, за потреби, можуть бути продовжені на визначений судом строк, але не більше ніж на дванадцять місяців. Ураховуючи тривалі строки застосування обмежувальних заходів, обгрунтовано постає питання про місце проживання особи, до якої застосовано заборону перебувати в місці спільного проживання з особою, яка постраждала від домашнього насильства, протягом періоду застосування заборони. Законодавство не дає відповіді на це запитання, водночас покладення на особу такої заборони навіть на найкоротший місячний строк вносить докорінні зміни в уклад iї життя, бо така особа, маючи у власності житло, фактично опиняється на вулиці [6, c. 298-301].

Наступним обмежувальним заходом є обмеження спілкування з дитиною в разі, якщо домашнє насильство вчинено стосовно дитини або в іiї присутності. Застосування такого заходу обмежує спілкування кривдника 3 дитиною. Таке обмеження може мати повний характер, тобто тотальна заборона на спілкування, а також обмеження за певних обставин, наприклад, заборона спілкування у стані сп'яніння, у нічний час, за відсутності певних осіб, за межами певної території. Інколи виникають питання, якщо в дитини немає інших близьких родичів або членів сім'ї, окрім особи, яка вчинила домашне насильство. Відповідно до листа Міністерства освіти і науки України від 18 травня 2018 р. № 1/11-5480 «Методичні рекомендації щодо запобігання та протидії насильству», за неможливості проживання дитини зі своїми батьками, іншими законними представниками у зв'язку зі вчиненням домашнього насильства стосовно цієї дитини або за іï участі служби у справах дітей влаштовують дитину в центр соціально-психологічної реабілітації дітей, притулок для дітей, інші установи для дітей, у яких створені належні умови для прожи- вання, виховання, навчання та реабілітації дитини відповідно до її потреб [7].

Згідно 3 п. 3 ч. 1 ст. 91-1 КК України, забороняється наближатися на визначену відстань до місця, де особа, яка постраждала від домашнього насильства, може постійно чи тимчасово проживати, тимчасово чи систематично перебувати у зв'язку з роботою, навчанням, лікуванням чи з інших причин. Вказаний обмежувальний захід передбачає заборону правопорушнику заходити до місця проживання жертви та до інших відповідних місць, які мають бути 3 подачі потерпілого визначені у вироку чи ухвалі суду. Визначена відстань повинна забезпечувати «фізичну дистанцію між жертвою та її кривдником». Як уважають, це має бути дистанція, яка не дозволяє ані доторкнутися до потерпілого, ані докинути до нього будь-який предмет, ані докричатися до нього (очевидно, не менше ніж 100-200 м) [8, с. 270].

Близьким до попереднього заходу є обмеження особи, яка вчинила домашнє насильство, щодо листування, телефонних переговорів з особою, яка постраждала від домашнього насильства, інших контактів через засоби зв'язку чи електронних комунікацій особисто або через третіх осіб. Поняттям «листування» охоплюється кореспонденція, яка передається поштовим зв'язком (листи, телеграми, бандеролі, інші письмові відправлення тощо) або електронною поштою, тобто через комп'ютер. Під телефонними розмовами слід розуміти розмови між особами, які відбуваються за допомогою будь-якого телефонного зв'язку, що здійснюється через провідні чи електромагнітні системи, мережу Інтернет тощо. До інших контактів через засоби зв'язку чи електронні комунікації можна віднести телеграфну кореспонденцію, повідомлення, зроблені телефаксом, за допомогою пейджингового зв'язку, інших телекомунікацій і електронних інформаційних систем [9, с. 83-86].

Прикладом може бути вирок Сокирянського районного суду Чернівецької області від 8 січня 2020 р. Особа 1 учинив психологічне насильство щодо своєї колишньої дружини, за що був засуджений за вчинення злочину, передбаченого ст. 126-1 КК України. Суд дійшов висновку, що до Особа 1 необхідно застосувати обмежувальний захід, заборонивши йому листування, телефонні переговори з Особа 2 (потерпіла), інші контакти через засоби зв'язку чи електронні комунікації особисто або через третіх осіб строком на три місяці. Суд уважає, що засуджений через такий обмежувальний захід не зможе вчиняти психологічне насильство щодо колишньої дружини [10]. 
I останній обмежувальний захід, який може бути застосований до особи, яка вчинила домашнє насильство, - це направлення для проходження програми для кривдників або пробаційної програми. Відповідно до ст. 1 Закону України «Про запобігання та протидію домашньому насильству», програма для кривдника - комплекс заходів, що формується на основі результатів оцінки ризиків і спрямований на зміну насильницької поведінки кривдника, формування в нього нової, неагресивної психологічної моделі поведінки у приватних стосунках, відповідального ставлення до своїх вчинків та їхніх наслідків, зокрема щодо виховання дітей, на викорінення дискримінаційних уявлень про соціальні ролі й обов'язки жінок і чоловіків [11]. Як бачимо, вказана програма спрямована на зміни у психіці та поведінці особи, яка вчинила домашнє насильство, шляхом переосмислення стосунків подружжя одне 3 одним, дітьми й іншими близькими родичами, яким може бути завдано шкоди.

Кривдник направляється судом на проходження відповідної програми для кривдників на строк від трьох місяців до одного року. Суб'єктами, відповідальними за виконання програм для кривдників, є місцеві державні адміністрації та органи місцевого самоврядування. За неявки кривдника для проходження програми для кривдників або ухилення від проходження програми без поважних причин суб'єкти, відповідальні за виконання цих програм, надають протягом трьох робочих днів письмове повідомлення про це уповноваженому підрозділу органів Національної поліції України для вжиття відповідних заходів [12, с. 83-86].

У разі застосування пробаційної програми особа, яка вчинила домашне насильство, направляється для проходження програми, передбаченої в п. 4 ч. 2 ст. 76 КК України. Відповідно до ст. 2 Закону України «Про пробацію», пробаційна програма - програма, що призначається за рішенням суду особі, звільненій від відбування покарання 3 випробуванням, та передбачає комплекс заходів, спрямованих на корекцію соціальної поведінки або іï окремих проявів, формування соціально сприятливих змін особистості, які можна об'єктивно перевірити [13].

Кривдник може бути направлений на проходження програми кривдника або пробаційної програми строком від трьох місяців до одного року. Судова практика показує, що суди застосовують як мінімальні, так і максимальні строки під час призначення програми кривдника або пробаційної програми. Наприклад, вироком Новоукраїнського районного суду Кіровоградської області від 22 січня
2020 р. до особи, яка вчинила злочин, передбачений у ст. 126-1 КК України, застосовано обмежувальний захід (п. 5 ч. 1 ст. 91-1 КК України) у вигляді направлення її для проходження програми для кривдників або пробаційної програми строком на три місяці [14]. А вироком Овідіопольського районного суду Одеської області від 8 листопада 2019 р. за вчинення домашнього насильства (ст. 126 КК України) до особи застосовано захід у вигляді проходження пробаційної програми протягом одного року [15].

\section{Висновки}

Внесення змін до кримінального законодавства і передбачення застосування обмежувальних заходів до особи, яка вчинила домашнє насильство, є позитивним кроком. Саме такі заходи дозволять захистити права й інтереси особи, яка зазнала фізичного, психічного або економічного насильства. Також обмежувальні заходи, передбачені у ст. 91-1 КК України, спрямовані на виправлення особи, яка вчинила таке насильство, шляхом переосмислення нею своєї поведінки до потерпілої особи, а також із метою запобігання вчиненню нових насильницьких злочинів. Звичайно, існують проблеми в судовій практиці щодо розуміння та застосування таких заходів. Тому необхідне подальше теоретичне та практичне розроблення позицій щодо застосування обмежувальних заходів у кримінально-правовій площині.

\section{Список використаних джерел:}

1. Про внесення змін до Кримінального та Кримінального процесуального кодексів України з метою реалізації положень Конвенції Ради Європи про запобігання насильству стосовно жінок і домашньому насильству та боротьбу із цими явищами : Закон України від 6 грудня 2017 р. № 2227-VIII. URL: https://zakon.rada.gov.ua/laws/ show/2227-19 (дата звернення: 15.01.2020).

2. Конвенція Ради Європи про запобігання насильству стосовно жінок і домашньому насильству та боротьбу із цими явищами. URL: http://search.ligazakon.ua/1_doc2.nsf/link1/ MU11251.html (дата звернення: 15.01.2020).

3. Науково-практичний коментар Кримінального кодексу України / за ред. М.І. Мельника, М.І. Хавронюка. 10-те вид. Київ : ВД «Дакор», 2018. $1360 \mathrm{c}$.

4. Ященко А.М. Обмежувальні заходи, що застосовуються до осіб, які вчинили домашне насильство: порівняльний аналіз кримінального законодавства України й окремих європейських країн. Вісник Кримінологічної асочіаиї України. 2018. № 2 (19). С. 35-45.

5. Вирок Петропавлівського районного суду Дніпропетровської області від 7 листопада 2019 р. Провадження № 1-кп/188/157/2019. URL: 
http://reyestr.court.gov.ua/Review/85516351 (дата звернення: 16.01.2020).

6. Крикливець Д.Є. Обмежувальні заходи за Кримінальним кодексом України. Порівняльноаналітичне право. 2018. № 2. С. 298-301.

7. Методичні рекомендації щодо запобігання та протидії насильству : лист $\mathrm{MOH}$ від 18 травня 2018 р. № 1/11-5480. URL: https://imzo.gov.ua/2018/05/21/lyst-mon-vid-1805-2018-1-11-5480-metodychni-rekomendatsijischodo-zapobihannya-ta-protydiji-nasylstvu/ (дата звернення: 16.01.2020).

8. Жук І.В. Обмежувальні заходи у кримінальному праві України : правова природа та сутність. Науковий вісник Ужгородського наиіонального університету. Серія «Право». 2019. Вип. 55. Т. 2. C. 83-86.

9. Вирок Сокирянського районного суду Чернівецької області від 8 січня 2020 р.
Провадження № 1-кп/722/20/20. URL: http://reyestr.court.gov.ua/Review/86789622 (дата звернення: 17.01.2020).

10. Про запобігання та протидію домашньому насильству : Закон України від 7 грудня 2017 р. № 2229-VIII. URL: https://zakon.rada.gov.ua/laws/ show/2229-19 (дата звернення: 17.01.2020).

11. Про пробацію : Закон України від 5 лютого 2015p.№160-VIII.URL:https://zakon.rada.gov.ua/ laws/show/160-19 (дата звернення: 19.01.2020).

12. Вирок Новоукраїнського районного суду Кіровоградської області від 22 січня 2020 р. Провадження № 1-кп/396/243/19. URL: http://reyestr.court.gov.ua/Review/87063174 (дата звернення: 25.01.2020)

13. Вирок Овідіопольського районного суду Одеської області від 8 листопада 2019 р. Справа № 509/2229/19. URL: http://reyestr.court.gov.ua/ Review/85485325 (дата звернення: 25.01.2020)

The article focuses on the institution of restrictive measures that are applied to persons who committed domestic violence. Within the framework of this investigation, the analysis of measures, provided by the Article 91-1 of the Criminal Code of Ukraine as amended by the criminal legislation, was carried out. It has been established that there are ambiguous interpretation of measures in the theory of the criminal law and in the judicial practice that can be applied to persons who have committed domestic violence. It is emphasized that restrictive measures are applied to a person who has been punished to a non-imprisonment sentence. Therefore, these measures are intended to perform the function of correcting the person without isolation from society, and to prevent crimes related to domestic violence. It is found out that restrictive measures contain a number of problems in their application in practice, as they do not comply with the norms of other branches of law. Besides, some measures restrict the rights and freedoms of a person, such as limitation of his/her movement or the ability to use his/her own housing. It must be remembered that the person, who has committed a crime, may be subjected to some restrictions, but they should not violate his or her rights and legitimate interests. It should also be noted that the application of restrictive measures are intended to protect and restore the violated rights of persons who have suffered physical, psychological or economic violence. Exactly the introduction of amendments to the criminal law is the consequence of the implementation of the Council of Europe Convention on the prevention of violence against women and domestic violence and combating these phenomena. The researched institute should serve as a deterrent tool in the field of combating domestic violence, which will protect the human right to freedom from violence. Therefore, in agreement with scientists and practitioners, restrictive measures should ensure that domestic violence in society is reduced.

Key words: domestic violence, restrictions, measures, probation program, offender program, criminal liability. 